\section{Grower Perspectives in Community Supported Agriculture}

\author{
Eva C. Worden ${ }^{1}$
}

Additional Index words. CSA, organic, motivations, information, extension

Summary. Community supported agriculture (CSA) is an alternative model of farming in which consumers become "members" of a farm, by contract, to receive a share of the harvest. Case study interviews were used to ascertain CSA grower perspectives, as indicated by sources of information and motivations. Like most organic growers, but unlike most conventional growers, few CSA growers have family background in agriculture. Common sources of information and strong informal communication were observed among CSA growers. Primary information sources include other growers, printed material, and conferences. Conventional sources of information used in agriculture, i.e., the cooperative extension system and formal agricultural education, appear to be underutilized and are ranked lowest in importance by CSA growers. CSA growers are motivated in their agricultural endeavors by multiple goals: marketing, education, community, and environment. Marketing was the most frequently cited primary goal, followed by education of consumers. For many CSA growers, the marketing motive is not solely monetary, but also philosophical, as a vehicle for achieving right livelihood and building an associative economy that redefines society's relationships to food and land.

$\mathrm{C}$ ommunity supported agriculture (CSA) describes a relationship of commitment

School of Forestry and Environmental Studies, Yale University, 205 Prospect Street, New Haven, CT 06511 .

Many thanks to Kristiina Vogt, John Wargo, William Burch, Kathryn Ruhf, and G.W. Stevenson for their invaluable assistance in this research.

${ }^{1}$ Currently assistant professor and extension specialist, University of Florida, Institute of Food and Agricultura Sciences, Fort Lauderdale Research and Education Center, Department of Environmental Horticulture, 3205 College Ave., Fort Lauderdale, FL 33314-7799. between consumers and a fresh-market produce grower. CSA consumers, or "members," provide a grower with advance payment for crops. The grower in turn provides the members with a weekly share of the season's harvest. The weekly share generally is composed of a variety of vegetables to supply a household with its produce needs. Often the share also includes fruit, herbs, and cut flowers.

CSA growers occupy a unique niche in agriculture by using organic, intensive cropping systems and receiving direct support from their membership (Worden, 2000). Agricultural production risks are shared partially with consumers, which offers greater financial stability to the grower. In the classic CSA model, the grower agrees to produce crops for the consumer, with the stipulation that if crops should fail due to weather, pests, or other uncontrollable factors, the advance payment is not refunded (Bowman, 1991).

CSA has been proposed as a model that potentially can overcome many challenges of fresh-market commercial agriculture. The CSA model has been described as: "an innovative and resourceful strategy to connect local growers with local consumers; develop a regional food supply and strong local economy; maintain a sense of community; encourage land stewardship; and honor the knowledge and experience of growers and producers working with small to medium farms" (University of Massachusetts Extension, 1996).

The objective of this research was to investigate key factors that might influence CSA growers' agricultural resource management behaviors, through case study interviews. CSA growers were asked about their motivations and sources of information for their agricultural endeavors.

\section{Materials and methods}

The study site of this research was within the Northeast Region of the United States Department of Agriculture (USDA) Sustainable Agriculture Research and Education (SARE) Program. This region includes the states of Connecticut, Delaware, Maine, Maryland, Massachusetts, New Hampshire, New Jersey, New York, Pennsylvania, Rhode Island, Vermont, and West Virginia.

Growers were questioned about their sources of information and responded from the following categories: 
commercial suppliers, conferences, cooperative extension, family background in agriculture, formal education in agriculture, other growers, or printed matter (journals, magazines, and books). Sources of information were coded with a rating of importance from 1-4 (low-high) based on the growers' responses.

Growers' motivations were assessed by inquiring about their goals in using the CSA model. Goals were coded into the categories of market, education, environment and community. Motivational philosophies underlying growers' goals are described qualitatively.

Case STUdy INTERViews AND ON-FARM OBSERVATIONS. Case studies are a standard method for in-depth investigation of small population groups (Yin, 1984), and therefore, seemed to be quite appropriate for studying CSA. Miller (1991) states that case studies offer researchers the ability to discover unique features and common traits shared by all persons in a given classification.

Semistructured case study interviews were used for data collection from 28 CSA growers. This sample represents slightly greater than $10 \%$ of the total population of 233 CSA growers in the geographic study area.

The case study subjects were selected to represent the larger CSA grower population in the USDA/ SARE Northeast region. This selection was based on findings of a "CSA Census," a self-administered survey of all known CSA farmers, which was conducted as one component of a larger USDA/SARE-funded study, and coordinated by the New England Small Farm Institute (Belchertown, Mass). The CSA growers that responded to the census $(\mathrm{n}=128)$ have a mean of 13.5 years of total agricultural production experience, and have been using the CSA model for a mean of 5.2 years (Worden, 2000). The population of case study subjects compares well with the CSA census survey population, with a mean of 11.8 years total production experience and a mean of 5.9 years CSA farming experience. Total production experience distribution of case study subjects also closely mirrors the larger CSA grower population (Fig. 1).

Case study interviews were conducted on the growers' farms. Data collected in the interviews were tri- angulated with on-farm observations and analysis of documents provided by growers. As is typical for descriptive case studies, many questions were open-ended (Fink, 1995). Responses to open-ended questions were coded, where appropriate. All of the interviews, in which questions were asked in a standard manner, were conducted by the author, to prevent unreliability that could arise from different interpretations made by interviewers. To minimize interpretive bias, the interviews were taped and fully transcribed. All interviewees appeared cooperative and were forthcoming with their responses. Each interview session took about $3 \mathrm{~h}$.

\section{Results and discussion}

Motivations. CSA growers cited multiple goals, including marketing $(93 \%)$, community $(64 \%)$, education (61\%) and environment (21\%). When asked what their primary goal was for using CSA, 54\% responded marketing, $21 \%$ education, $14 \%$ community, and $11 \%$ environment, $11 \%$.

Consistent with these findings, Laird (1995) found that many CSA growers have felt successful in raising awareness by educating and inspiring children and helping people understand the community building process. Laird also reported that the guaranteed market of the CSA model was for many growers a primary attraction to CSA.

There are important philosophical dimensions to growers' motivations that cannot be captured in the simplified categories and numbers listed above. For example, one case study subject expressed a motivation to derive fulfillment from agricultural activities, and to share this potential for self-actualization with others:

I believe everybody should play in the dirt. I think we would have a much happier world, and also be in touch with our food. People lose touch with basic things I think. I wish more people could do it ... If I had one wish for everybody it would be that they have a garden. You can find yourself in the garden.

For many CSA growers in this study, the "marketing" motivation is but a necessary pre-condition to actualizing a deeper philosophy of "right livelihood," or meaningful work. For example, one grower relates:

All of us human beings yearn to have work that has meaning, not just dull, stultifying, boring work, even though it may make us a lot of money ... It sounds so inimical to the modern global economy, the present economic system-but one can still hope and dream that people are able to find work that connects them in a more intimate way with other people, with their neighbors particularly.

Several CSA growers view the marketing goal as one of building an alternative, associative economic system. As one grower says:

In CSA is the seed of a new way of doing economics-a collaborative way-where consumer and producer or distributor are not blindly putting their products out into the

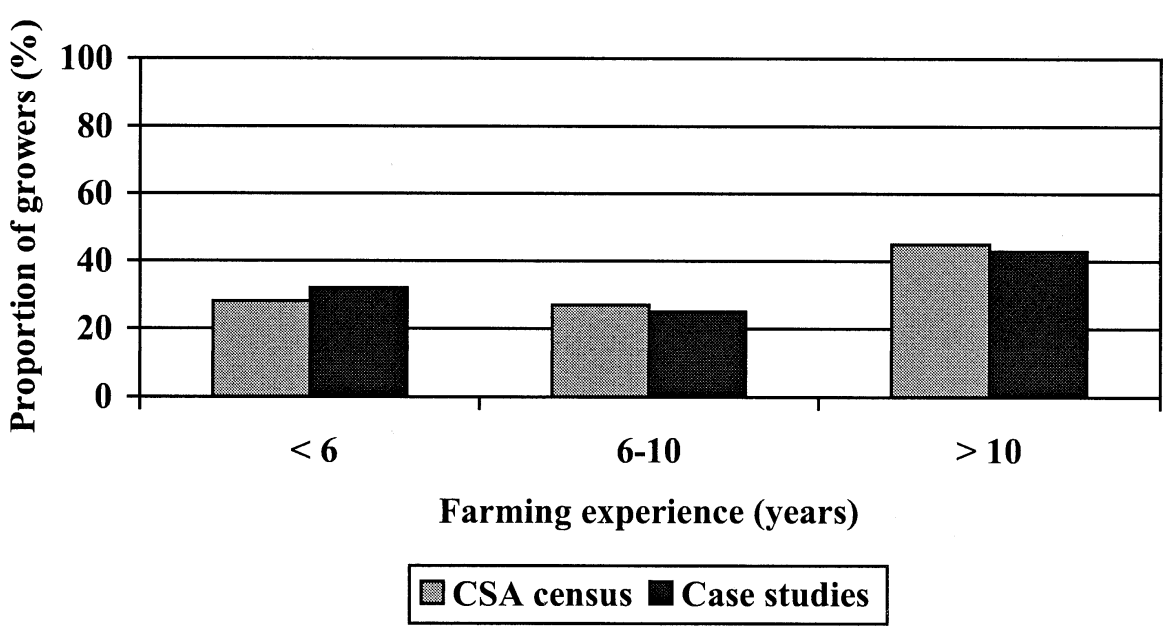

Fig. 1. Number of years farming experience for community supported agriculture (CSA) growers in CSA census $(n=128)$ and CSA case studies $(n=28)$. 
open market, the 'invisible hand' of the open market, but they are making conscious economic relations... We feel very strongly that actually agriculture is the foundation of everybody's economic life, even though it's not recognized as such right now.

An associative economy, in contrast to the existing market economy, is founded on the philosophy that direct, informed human relationships between producer and consumer in the exchange of goods and services results in greater equity and satisfaction for all parties involved (Lamb, 1996). Growers who share this philosophy view CSA as an example of such a direct, informed relationship. Is the CSA model the only route to an associative economy in agriculture? A grower at one of the largest and oldest CSA farms in the country thinks not:

CSA is the current form or incarnation of a bigger idea of an associative relationship between farmers and consumers which doesn't necessarily have to take this current form, and probably won't. In a few years it might evolve in some direction or another, with the idea of sharing responsibility for land and food, and those things may be the bigger goal.

Sources of information. Case study subjects develop their knowledge base of agriculture from several information sources (Table 1). The highest ranked information source for these CSA growers is other growers (mean $=3.7)$. This category includes other CSA growers, organic growers, and conventional growers, but primarily is composed of other CSA growers.

Table 1. Agricultural information sources of community supported agriculture growers from case study interviews $(n=28)$.

\begin{tabular}{lc}
$\begin{array}{l}\text { Source of } \\
\text { knowledge }\end{array}$ & $\begin{array}{c}\text { Mean rating } \\
(\mathbf{1}=\mathbf{l o w} \text { to } \\
\mathbf{4}=\mathbf{~ h i g h})\end{array}$ \\
\hline Other growers & 3.7 \\
Printed matter & 3.5 \\
Professional conferences & 3.2 \\
Commercial suppliers & 2.4 \\
Family background & 2.2 \\
Formal agricultural education & 1.9 \\
Cooperative extension system & 1.9 \\
\hline
\end{tabular}

Printed matter $($ mean $=3.5)$ and conferences $($ mean $=3.2)$ also ranked rather high as information sources for the case study population. Growers frequently referred to the same journals, magazines and books, especially the periodical Growing for Market (published monthly by Fairplain Publications, Lawrence, Kans.), and the books of Eliot Coleman (1992, 1995). CSA growers attend the Northeast Organic Farming Association conferences and USDA/SARE-funded regional CSA conferences and cited these meetings as particularly educational.

Commercial suppliers of agricultural products are ranked somewhat lower $($ mean $=2.4)$. Those growers who obtain information from commercial suppliers indicated that they benefit from reading sales literature and from talking with sales representatives. Most frequently cited were seed, irrigation, and equipment companies for crop production and technical information. Growers tended to name the same commercial suppliers, particularly seed and equipment companies.

Few growers interviewed have direct family background in agriculture $($ mean $=2.2)$. Twenty-eight percent of CSA growers in the northeastern United States have fewer than 5 years experience in farming. The following statement represents the agricultural heritage of many: "Zilch . . . as you go back generations, no farmers, they're all merchants and schoolteachers."

This is consistent with the fact that as a whole, organic farmers tend to be first-generation farmers (McCann et al., 1997). By comparison, Fernandez-Cornejo et al. (1998) indicate that $87 \%$ of conventional farmers have some family farming background.

Those who have adopted the CSA model primarily come from two distinct populations: experienced organic vegetable growers, and inexperienced non-farmers. All experienced growers who adopted CSA previously were operating farms with diversified organic vegetable cropping systems, mostly with direct retail sales, such as farm stands or farmers markets. Many of the inexperienced non-farmers have participated in CSA apprenticeships or intensive on-farm CSA training programs, such as Collaborative Regional Apprentice Farmer Training (CRAFT).

As many sectors of agriculture are experiencing an exodus, CSA is expe- riencing an influx. This may be due in part to the fact that established growers within the CSA network have worked to share their knowledge by creating apprenticeship-training programs such as CRAFT.

The cooperative extension systems and agricultural formal education share the lowest ranking as information sources $($ mean $=1.9)$. These two categories are the mainstays of traditional, mainstream agricultural information transfer in the United States, however, they apparently are not used to a great extent by CSA growers.

Several growers indicated that they had attempted to obtain information from the cooperative extension system, but that extension provides few services that they can use. For example, one grower reveals:

The few times I talked to extension, because [my farm is] so small, they really didn't want to give me the time of day, so I just said, the hell with them, and I'll find it in other sources, which I have. So, unfortunately, I think they're geared to the larger farmer and not the small farmer, which is a shame, because I think [this state] could do well with a lot of small farms and not the mega-farming.

In another grower's experience, cooperative extension has not supplied useful information for her farming system because they favor large-scale agriculture. She believes that the structure and funding mechanisms of the extension system give priority to "big farming":

We have contacted [the local extension agents], but they tend not to like us too much ... one time when I saw him at a meeting someplace, he said, "you [CSA farmers] have to get your act together"... he seemed to have a pretty bad attitude, rather than saying "what can I do to help?”... This book that I read, it helped me understand extension a little better and some of the reaction we were getting. It talked about the connection between extension and the farmers-where the money comes from. I know CSAs don't provide any money, or most of them don't because they're just on the edge of extinction themselves. So, I think extension tends to lean more to where the money is-where the big farming is. 
Most CSA growers do not view their local extension system as a useful information source. However, several growers did name particular extension faculty members who provide useful information to them by extending their outreach to the entire region.

"Formal agricultural education" in this research refers to postsecondary schooling in plant or animal science from any institution of higher education. This category ranked low as an information source, however, several CSA growers interviewed do have advanced degrees, including masters or doctoral degrees, in other areas. For some examples, one grower studied mathematics in college, another earned a master's degree in environmental management, and yet another holds a doctorate in Slavic languages.

A lack of formal education in agriculture and minimal use of the extension system reveals that CSA growers have limited exposure to traditional, mainstream agricultural information. This is useful for those who wish to evaluate and supplement the knowledge base of this population.

CSA growers' similar agricultural resource management behaviors can be understood by taking the findings of this study in the context of reference group theory. Shibutani (1968) describes a reference group as one whose outlook is used by the actor as the frame of reference in the organization of his perceptual field. Through participation in common communication channels, common perspectives emerge in a reference group.

\section{Conclusion}

This research indicates that CSA growers belong to a reference group, and share a common agricultural per- spective, thus explaining their similar agricultural resource management behaviors. The findings of this study suggest that agricultural educators might see opportunities to successfully provide communication and outreach to CSA growers via train-the-trainer programs, articles in selected alternative agriculture publications, and professional conferences geared to this expanding client group. The publications and conferences favored by CSA growers in the northeastern United States tend to be national in scope. Therefore, outreach efforts using those channels may also have an impact on growers in other regions of the United States. To increase adoption of the CSA model, a feasible target audience would be fresh-market vegetable growers with several years of production experience who currently use retail sales strategies. Motivations and philosophies of CSA growers should be considered when designing outreach programs.

\section{Literature cited}

Bowman, G. 1991. Farms for members only. The New Farm 13(1):16-19.

Coleman, E. 1992. The new organic grower's four-season harvest: How to harvest fresh, organic vegetables from your home garden all year long. Chelsea Green Publ., White River Junction, Vt.

Coleman, E. 1995. The new organic grower: A master's manual of tools and techniques for the home and market gardener. Chelsea Green Publ., White River Junction, Vt.

Fernandez-Cornejo, J., C. Greene, R. Penn, and D. Newton. 1998. Organic vegetable production in the U.S.: Certified organic growers and their practices. Amer. J. Alternative Agr. 13(2):69-78.
Fink, A. 1995. The survey handbook. SAGE Publ., Thousand Oaks, Calif.

Lamb, G. 1996. Community supported agriculture: Can it become the basis for a new associative economy? 1996 CSA Farm Network Bul. 1.

Laird, T.J. 1995. Community supported agriculture: A study of an emerging agricultural alternative. Masters Thesis, Dept. of Natural Resource Planning. Univ. of Vermont, Burlington.

McCann, E., S. Sullivan, S.D. Erickson, and R. De Young. 1997. Environmental awareness, economic orientation, and farming practices: A comparison of organic and conventional farmers. Environ. Mgt. 21(5):747-758.

Miller, D. 1991. Handbook of research design and social measurement. SAGE Publ., Newbury Park, Calif.

Shibutani, T. 1968. Reference groups as perspectives, p.103-113. In: H.H. Hyman and E. Singer (eds.). Readings in reference group theory and research. The Free Press, New York.

UMass Extension.1996. What is community supported agriculture and how does it work? Univ. of Mass., Amherst. 2 Sept. 2003. http://www.umass.edu/umext/ csa/about.html.

Worden, E.C. 2000. Community supported agriculture: Land tenure, production systems, social context, and grower perspectives. PhD Diss., School of Forestry and Environ. Studies, Yale Univ., New Haven, Conn. (Diss. Abstr. AAT 9991140.)

Yin, R.K. 1984. Case study research: Design and methods. SAGE Publ., Beverly Hills, Calif. 